\title{
Cultural Aspects in the Shona Monolingual Dictionary Duramazwi Guru reChiShona*
}

\author{
Nomalanga Mpofu, African Languages Research Institute, University of \\ Zimbabwe, Harare, Zimbabwe (nmpofu@arts.uz.ac.zw)
}

\begin{abstract}
In the compilation of dictionaries, lexicographers also take cognisance of the culture which is inherent in a language. This article will look at the way the cultural aspect is interwoven in the practice of dictionary making. Language is at the core of culture and it is the major vehicle for the transmission of a people's beliefs and values. Language is also an expression of social structures and attitudes. No culture can exist which does not have a natural language at its centre. A language thus reflects a particular culture. Culture in this article will be taken to mean whatever a person must know in order to function in a particular society (Wardhaugh 1998: 215). The article will look at two aspects: (1) the interrelationship between language and culture and its bearing on lexicography; and (2) the treatment of cultural aspects in Duramazwi Guru reChiShona (2001). Examples used in this article are drawn from the advanced Shona monolingual dictionary Duramazwi Guru reChiShona, and other Shona dictionaries, both monolingual and bilingual.
\end{abstract}

Keywords: CULTURAL COMPETENCE, CULTURAL ASPECTS, CULTURAL MEANING, CULTURE, DICTIONARY, EUPHEMISM, EXTENDED MEANING, IDIOM, LEXICOGRAPHY, PROVERBS, SHONA, SHONA SOCIETY, TABOO

Opsomming: Kulturele aspekte in die Sjona- eentalige woordeboek. By die samestelling van woordeboeke neem leksikograwe ook kennis van die kultuur wat inherent aan ' $n$ taal is. Hierdie artikel sal kyk na die manier waarop die kulturele aspek verweef is met die praktyk van woordeboekmaak. Taal lê aan die kern van kultuur en dit is die hoofmedium vir die oordrag van ' $n$ volk se opvattings en waardes. Taal is ook 'n uitdrukking van sosiale strukture en houdings. Geen kultuur kan bestaan wat nie 'n natuurlike taal as middelpunt het nie. ' $n$ Taal weerspieël gevolglik 'n bepaalde kultuur. Kultuur in hierdie artikel sal verstaan word om alles te beteken wat 'n persoon moet weet om in 'n betrokke maatskappy te funksioneer (Wardhaugh 1998: 215). Die artikel sal na twee aspekte kyk: (1) die onderlinge verband tussen taal en kultuur en die betrekking daarvan op die leksikografie; en (2) die behandeling van kulturele aspekte in Duramazwi Gura reChiShona (2001). Voorbeelde wat in hierdie artikel gebruik word, is afkomstig uit die gevorderde Sjona- eentalige woordeboek Duramazwi Guru reChiShona, en ander Sjonawoordeboeke, sowel eentalig as tweetalig.

Sleutelwoorde: EUFEMISME, IDIOOM, KULTURELE ASPEKTE, KULTURELE BETEKE-

* This article was presented as a paper at the Seventh International Conference of the African Association for Lexicography, Rhodes University, Grahamstown, 8-10 July 2002.

Lexikos 13 (AFRILEX-reeks/series 13: 2003): 232-239 
NIS, KULTURELE VAARDIGHEID, KULTUUR, LEKSIKOGRAFIE, SJONA, SJONASAMELEWING, SPREEKWOORDE, TABOE, UITGEBREIDE BETEKENIS, WOORDEBOEK

\section{Introduction}

The purpose of this article is to highlight cultural aspects in Duramazwi Guru reChiShona (2001), the advanced monolingual Shona dictionary (hereafter referred to as Duramazwi). Culture, according to Wardhaugh (1998: 215), is defined as whatever a person must know in order to function in a particular society. In Shona society, this cultural knowledge entails knowing how to address elders and how to behave in their presence, the difference between being polite and being impolite, what not to say in public, and how to speak about certain subjects. All this knowledge is acquired socially through interaction. Wolff (2000: 302) notes that cultures and societies dictate to a person when to speak or to be silent, and which vocabulary items or formulaic expressions to choose or avoid.

Cultural aspects in this article will be taken to encompass everything that a person has to know in order to function effectively in a particular society. This includes language use which in turn includes veiled and loaded language such as euphemisms and sense extensions. The term will also cover those practices and beliefs characteristic of Shona tradition.

Several aspects found in the Shona language and culture were incorporated in Duramazwi. These cultural aspects include sensitive and offensive terms, terms with extended meanings, kinship terms, cultural practices, proverbs and idioms. These depict the Shona way of life, beliefs, norms and values. It is only those cultural aspects which are verbal which can be captured in a dictionary, yet in Shona there are a sizeable number of non-verbal cultural aspects that are part of day-to-day life. For instance, it is rude in Shona society to hand something to someone older than you using only one hand. It is also required that one claps one's hands when accepting something from someone older. There is no way that these cultural aspects can be included in a dictionary. It is the purpose of this article to analyse how cultural aspects were treated in Duramazwi. The article will address two aspects: (1) the interrelationship existing between language, culture and lexicography; and (2) the treatment of these cultural aspects in the Duramazwi.

\section{The Interrelationship between Language, Lexicography and Culture}

Language is at the core of culture and no culture can exist which does not have at its centre a natural language. A language thus reflects a specific culture (Mpofu 2001: 246). Culture is a people's way of life. Two linguists, Edward Sapir (1921) and Benjamin Lee Whorf (1956), wrote extensively on the relationships existing between language and culture. Their findings came to be referred to as the Sapir-Whorf hypothesis which postulates that language and cul- 
ture are inextricably related, so that one cannot be understood or appreciated without knowledge of the other. Although this article acknowledges this hypothesis, it will not be a sociological study of language, but an examination of the issues from a lexicographic point of view.

The primary purpose of any dictionary is meaning. But one cannot talk about the meaning of a word without recognising the wider social and cultural reality of the language in question. In other words, society's norms and expectations govern what should be included in a dictionary and how it should be treated. In any language, certain things are not expressed, not because they cannot be, but because people avoid talking about these things (Wardhaugh 1998: 234). According to Svensén (1993: 45), the use of language is influenced not only by linguistic norms but also by social standards. Certain words are socially charged because of being considered by many to be offensive. That is why certain entries in Duramazwi were given stylistic markers or labels, e.g. tuko (short for chituko - offensive words); and nyadzo (short for chinyadzo taboo words). Some users would expect words considered by society as offensive or sensitive to be in a dictionary, but because of the linguistic taboo observed in Shona society concerning these words, they were marked or labelled, and defined in as neutral a way as possible. This usage labelling gives information on constraints on the use of these words. According to Kipfer (1984: 6), language is no longer considered as either correct or incorrect, but lexicographers and linguists agree that importance has to be placed on actual usage. In line with this view, Landau (20012: 233) states that the decision of dictionary editors on what to label offensive or disparaging is based on their judgment of society's norm for the limits of reputable public behaviour.

As far as the treatment of these terms are concerned, the compilers of Duramazwi were faced with the challenge of how to be precise in defining them, yet at the same time conforming to the cultural norms of the language.

\section{Euphemisms}

The use of euphemisms is also prevalent in the Shona language and society. A euphemism is a polite word or expression used to speak about something found unpleasant or embarrassing, such as death or sex. The purpose of euphemisms in language is thus to avoid directly mentioning certain things. In Shona, for example, one does not directly speak about death. When informing someone that a person has died, one does not usually use the more direct word $k u f a$. People rarely say, Nhingi afa (so and so has died), but rather refer to death as kupfuura (to pass on), kuenda (to go), kutisiya (to leave us behind), kutungamira (to go ahead of others), kufuka rako woga (to be alone under your bedcovers), kuenda kwamupfiganebwe (to go to the place whose entrance is closed by a stone). They may also say, Nhingi hakusisina (so and so is no longer there). Such euphemisms are also meant to lessen the pain and fear associated with death. In Duramazwi, apart from the words rufu (death) or kufa (to die), one also finds 
-shaya (to lose), and -shayika (to fail to be located/found). Even terms referring to burial are euphemistic, e.g. kuchengeta (to keep), kuradzika (to lay down), kuviga (to hide something), kukotsa (to hide something).

Sex in Shona society, like in other societies, is also one of the least talked about subjects in public. If people have to talk about it, they do so using veiled language. Hence in Duramazwi one finds entries such as -sangana (to meet), -rara (to sleep), and -ziva (to know something or someone) which also refer to sexual intimacy. The sexual act itself is commonly referred to as bonde (reed mat). Even terms that refer to pregnancy and giving birth are euphemistic. People prefer to use polite expressions such as kuzvitakura and kuzvisenga (to carry oneself), and kutsika mwedzi (to step on the moon) to refer to the state of pregnancy, and instead of the more direct word kuzvara (to give birth), kubatsirwa (literally, to be helped) and kusununguka (literally, to be free) to describe the act of giving birth.

Sex and anything that is associated with it is one of the most tabooed subjects in Shona, both in the public and private domain. The genitals or sexual organs are therefore also not directly referred to. Both the penis and vagina are politely called sikarudzi (creator of a clan). Other names euphemistically used for the penis are mhuka (animal), chirema (cripple), chombo (weapon), and mbonausiku (that which sees at night), and for the vagina kunzira kwaamai (the woman's passageway) or mukana (passageway).

Sexually transmitted diseases are also referred to indirectly in Shona. For instance, the general term commonly and politely used for these diseases is chirwere chepabonde (the disease of the reed mat) as opposed to direct terms such as siki (sexually transmitted disease), and more specifically gonoriya (gonorrhea) or songeya (syphilis). When one admits to be suffering from a sexually transmitted disease, one usually says ndakarumwa (I was bitten). Acquired immunodeficiency syndrome (AIDS) is referred to as shuramatongo (that which brings about desolate homes) because of the way it can wipe out whole families. The term shuramatongo, before its sense extension, means "a person who is an expert at something, either a sport or a craft" (Hannan 1984: 609, Chimhundu 2001: 932).

\section{Sense extensions}

Words that have cultural meanings in Shona are mostly nouns and verbs with extended meanings or sense extensions. In order to understand such terms one needs to have cultural competence in the values of the Shona people. A particular group of people or a specific culture has certain things it reveres and observes. Frake (1964: 260) says of culture:

Goodenough (1957) has proposed that a description of a culture - an ethnography - should properly specify what it is that a stranger to a society would have to know in order appropriately to perform any role in any scene staged by the society. 
For instance, the verb kukotsira (to sleep) can also be used to refer to a slow or stupid person. Thus, if one says Nhingi akakotsira (so and so is asleep), it not only means that the particular person is sleeping but it can also mean that he/she is dull. Munhu literally means a person in Shona, but it also means that the person referred to is morally upright and has a good social standing. It is an insult to say of someone Nhingi haasi munhu (so and so is not a person) for this is a deriding and demeaning statement about a person's character. The sense of munhu when used in the context ndinongova munhu can mean that the person of whom is spoken, has no money at the moment of speaking. Musikana (girl) can also refer to a virgin and mukomana (boy) to a bachelor. Bofu is a blind person, but also refers to a dull student or person. While chirema is a cripple, it also refers to a heavily pregnant woman as well as to the male sexual organ. It can also be used to refer to someone who is unable to do anything useful or meaningful in life, or someone who cannot easily do what his/her peers do. Kufamba-famba means "to walk about" but it also refers to sexual immorality.

\section{Cultural terms}

\section{(a) Kinship terms}

Kinship terms are an integral part of the Shona societal system. There is a sizeable lexicon in Shona that refers to this cultural concept and most, if not all of these words with their different senses were captured in Duramazwi. A few can be picked for illustrative purposes. A young girl calls her father's older brother babamukuru (literally, older father = uncle) and his younger brother babamunini (literally, younger father = uncle) and they in turn call her mwana (child/ daughter). She calls her mother's brother sekuru (uncle) and he in turn calls her muzaya (niece). Her father's sister's husband is called babamukuru (uncle) and he in turn calls her mainini (loosely, young wife), and at times can also refer to her as his wife because in traditional Shona culture when a woman dies, her brother's daughter can be an eligible wife for the widowed husband. In cases of barrenness on the wife's part, the uncle could also marry her. The young Shona girl furthermore calls her mother's older sister's husband babamukuru (uncle) and the younger sister's husband babamunini (uncle). In Duramazwi the entry for babamukuru covers all these senses:

babamukuru DKDKK z 1a. Mubereki kana muramu wechirume mukuru (parent or sister's husband or father's sister's husband). 1 Uyu mukoma wababa (father's elder brother). 2 Uуи murume wavatete (father's sister's husband). 3 Uyu murume wasisi vako, kana uri mukadzi (sister's husband, if you are female). 4 Uyu murume womukoma womudzimai wako (wife's elder sister's husband) ...

According to Wardhaugh (1998: 226), it is important to remember that when a term is used in a kinship system, it carries with it ideas about how such people 
ought to behave toward others in the society using that system. This also holds true of Shona society where the term by which you refer to a member of the family, especially of the opposite sex, governs your behaviour towards that person. For instance, if a person is your muramu (wife's sister, wife's brother's daughter, or husband's younger brother), there is linguistic license whereby you may joke with that person regardless of the context. In Shona there is the saying Muzukuru mukadzi (Your sister's daughter is your wife) and the proverb Muzukuru mudonzvo wepwa, ukanzwa nzara unomenya uchidya (Your sister's daughter is like a sugar-cane walking-stick, if you feel hungry you can peel and eat it, that is, a man can take his sister's daughter as his wife should he so wish). This saying and proverb show that the relationship existing between a man and his sister's daughter does not restrict them from falling in love with each other. The opposite situation prevails when a man refers to a female kin as ambuya (wife's brother's wife), while she in turn calls him mukwasha (husband's sister's husband). In this case, linguistic and social distance is observed and in strict societies the two are not even allowed to shake hands or sit in the same room for extended periods of time.

\section{(b) The roora (lobola) custom}

Duramazwi also portrays customs considered to be culturally important to the Shona people. One of these is the roora (lobola) custom. Roora is the money and/or cattle a man pays to his in-laws as a way of seeking permission to live with their daughter as his wife (Mpofu 2001: 247). According to Kavanagh (2000: 103), the vocabulary of a language can provide some evidence of what is considered culturally important, and there may be several words for the most familiar items and concepts. There is a sizeable lexicon on the roora custom in the Shona language. These cultural terms were also incorporated in Duramazwi, which is an indication of their importance to the Shona people.

One such term is rusambo or rugaba, money, excluding the cattle, paid as roora. Another example is the term makandinzwanani (literally, who informed you of me?), which refers to money paid by the son-in-law as a way of introducing himself to his in-laws. Vhuramuromo or zaruramuromo (open the mouth), another of the roora custom settlements, is money paid by the son-in-law to enable the marriage negotiations to start.

One also finds the terms danga (literally, a kraal, but also cattle paid as part of roora), munyai (go-between), masungiro (goat or money paid to in-laws when the daughter goes to deliver the first child), matekenyandebou (money paid to the father-in-law for rearing the daughter, literally, for the fact that the daughter used to play with her father's beard), and mapfukudzadumbu (money paid to the mother-in-law in appreciation for the time she carried her daughter in her womb). In the roora custom, the father-in-law makes many impositions regulated by the culture within which this custom is enshrined. 


\section{(c) Proverbs and idioms}

Proverbs were given lemma status in Duramazwi. Duramazwi is divided into two parts, the first part being the A-Z section of the dictionary including idioms and the second part consisting of proverbs and pithy sayings. Proverbs are important to the Shona people because of their didacticism. They were given lemma status in Duramazwi because they form an integral part of Shona discourse. Proverbs can be applied to real life situations as warnings against certain types of behaviour or as words of advice. Among the Shona, proverbs are a versatile medium of communication in that they can be used on any occasion and in any context. According to Pongweni (1989: 1), proverbs derive from, and express the communal view of the world based on firsthand experience.

In Duramazwi one thus finds a sizeable number of proverbs, which, when looked at carefully, show similar themes running across them such as communal living and working together, valuing the little you have and discouraging envy. Pongweni (1989: 13) notes that figurative language of all types and from all communities derives its imagery from the environment in which the speakers of the language live. The following sample of proverbs instruct against individualism and being unappreciative of that which you possess:

Chara chimwe hachitswanyi inda (literally, one finger cannot crush a louse, i.e., individualism has no gain)

Rume rimwe harikombi churu (literally, one man cannot surround an anthill, i.e., individualism has no gain)

Tsapata rukukwe hazvienzani nekurara pasi (literally, a worn-out reed mat is better than sleeping on the floor, i.e., half a loaf is better than nothing)

Chembere mukadzi, hazvienzani nekurara mugota (literally, an old woman is a wife, she is better than sleeping alone in a bachelor's hut, i.e., half a loaf is better than nothing)

Idioms, like proverbs, are also a versatile feature of figurative language used on various occasions. Examples are: kuruma nzeve (to bite someone's ear $=$ to advise), kubaya dede nomumukanwa (to pierce the baboon through the mouth = to do something accurately), kudya magaka mambishi (to eat raw cucumbers = to have a fiery temperament), kubata kumeso (to touch one's face $=$ to deceive), and kugara maoko (to sit on one's hands = to be lazy and unproductive).

\section{Conclusion}

This article has attempted to show that one cannot speak of language without referring to the culture embodied in that language. A dictionary is a record of actual usage. It is therefore expected to meet the different needs of its different users. It should also be able to tell the user what the word means and how that 
word may be used. The aspect of usage is of relevance to culture because words are used differently in different cultures. What may be deemed proper in one culture may be viewed differently in another.

Cultural items form an integral part of a language, hence they merit inclusion in a dictionary. Their importance in a dictionary hinges on the fact that they mirror what is considered important by the people whose language is being described and who participate in the culture which embodies that language.

\section{References}

Chimhundu, H. (Ed.). 2001. Duramazwi Guru reChiShona. Harare: College Press.

Frake, C.O. 1964. How to Ask for a Drink in Subanum. Pride, J.B. and J. Holmes. 1972. Sociolinguistics. Harmondsworth: Penguin Books.

Goodenough, W.H. 1957. Cultural Anthropology and Linguistics. Garvin, P.L. (Ed.). 1957. Report of the Seventh Round Table Meeting on Linguistics and Language Study. Washington, DC: Georgetown University Press.

Hannan, M. 1984. Standard Shona Dictionary. Harare: College Press.

Kavanagh, K. 2000. Words in a Cultural Context. Lexikos 10: 99-110.

Kipfer, B.A. 1984. Workbook on Lexicography: A Course for Dictionary Users with a Glossary of English Lexicographical Terms. Exeter: University of Exeter.

Landau, S.I. 2001². Dictionaries: The Art and Craft of Lexicography. Cambridge: Cambridge University Press.

Mpofu, N. 2001. Problems of Equivalence in Shona-English Bilingual Dictionaries. Lexikos 11: 242251.

Pongweni, A.J.C. 1989. Figurative Language in Shona Discourse. Gweru: Mambo Press.

Sapir, E. 1921. Language: An Introduction to the Study of Speech. New York: Harcourt, Brace and Co.

Svensén, B. 1993. Practical Lexicography: Principles and Methods of Dictionary Making. New York: Oxford University Press.

Wardhaugh, R. 1998. An Introduction to Sociolinguistics. Oxford: Basil Blackwell.

Whorf, B.L. 1956. Language, Thought and Reality. Edited with an introduction by J.B. Carroll. Cambridge, Mass.: Massachusetts Institute of Technology / New York: John Wiley and Sons.

Wolff, H.E. 2000. Language and Society. Heine, B. and D. Nurse. 2000. African Languages: An Introduction. Cambridge: Cambridge University Press. 